\title{
Effect of genetic relatedness among parents on gain in salt tolerance in progeny of crosses of Eucalyptus occidentalis
}

\author{
By R. Hendrati' ${ }^{1)}$, M. Byrne ${ }^{\left.1,2),{ }^{*}\right)}$, E. Barbour ${ }^{3)}$ and J. Plummer ${ }^{1)}$
}

(Received $6^{\text {th }}$ March 2009)

\begin{abstract}
Genetic diversity of a Eucalyptus occidentalis breeding population screened for salt and waterlogging tolerance was examined using eight microsatellite loci. Mating using an immature style 'one stop pollination' method between parents was carried out to produce progeny for testing under $500 \mathrm{mM}$ salt waterlogging. The effect of parental genetic distance on seed production and early seedling survival was examined and inheritance of salt/or waterlogging tolerance was assessed by testing performance of progeny in comparison to parents. Diversity was moderate among the nine provenances and the families, and most of the diversity was distributed within rather than between families. Genetic relationships showed no structure in relation to provenance indicating any adaptation to saline environments has not affected genetic similarity. Breeding for salt and water tolerance may be achieved without decline in genetic diversity. There was a significant correlation between capsule production and parental genetic distance and a positive trend between increasing parental genetic distance and increasing number of germinated seeds/capsule, and seedling survival at 2 weeks and 9 months. These trends indicate expression of inbreeding depression in crosses between genetically similar parents. Heritability values, under $500 \mathrm{mM}$ saltwaterlogging treatment, indicated that height had moderate heritability $\left(h^{2}=0.5\right)$. Crosses with the widest parental genetic distance produced progeny with considerable height increase above parents and this trend was evident even with moderate genetic distance indicating crossing at this level of differentiation may achieve optimum breeding gain.
\end{abstract}

Key words: eucalypts, salt tolerance, genetic diversity, flat topped yate, microsatellite, inbreeding.

\section{Introduction}

Breeding involves selection of individuals with superior performance followed by mating between superior plants to achieve further genetic gain. Genetic diversity of the base population is a fundamental basis for breeding and improvement programs since selection of superior genotypes for tolerance, growth or other traits may

\footnotetext{
1) School of Plant Sciences, The University of Western Australia, Crawley, WA 6917, Australia.

2) Science Division, Department of Environment and Conser vation, Locked Bag 104, Bentley Delivery Centre, WA 6983, Australia.

3) Forest Products Commission, Locked Bag 888, Perth Business Centre, WA 6849, Australia.

*) Corresponding author: M. ByRNe. Science Division, Department of Environment and Conservation, Locked Bag 104, Bentley Delivery Centre, WA 6983, Australia. E-Mail: Margaret.Byrne@dec.wa.gov.au
}

erode genetic variation in the breeding population (ELDRIDGE et al., 1994). Limited diversity in the base population increases the likelihood of producing closely related or inbred progeny with reduced fitness.

Generally there is an optimum genetic distance for mating at which maximum genetic gain is obtained. Breeding between closely related plants commonly results in expression of inbreeding depression caused by combining deleterious recessive genes in the homozygous state, leading to reduced fitness. Conversely, breeding between widely differentiated individuals can lead to outbreeding depression due to disruption of local adaptation, under-dominance or epistatic interactions, and the breakdown of co-adapted gene complexes (EDMANDS, 2007). Inbreeding depression is commonly expressed in forest trees as they tend to have highly outcrossed mating systems. In Eucalyptus this outcrossed mating system masks the effects of post zygotic lethal systems that eliminate the effects of selfing in natural populations. In eucalypt breeding programs inbreeding depression has been shown to have significant effects on seed production and on progeny growth performance (GRIFFIN and COTTERIL, 1988; HARDNER and TIBBITS, 1998), therefore breeding is best carried out between genetically diverse parents. Generally in eucalypt breeding, there is little or no artificial mating as it is very costly. However, controlled pollination between superior individuals is an effective way to combine the best alleles in future generations and maximise genetic gain through breeding (MONCUR, 1995; HARBARD et al., 1999).

Eucalyptus occidentalis Endl. (flat-topped yate), is a tall timber species reaching $10-20 \mathrm{~m}$ in height with diameter at breast height up to $0.5 \mathrm{~m}$ (FAO, 1981; MARCAR et al., 1995). The timber is suitable for building poles, pilings, posts, heavy construction and for pulp (Clark et al., 1999; HARWOOD, 2001; MARCAR and CRAWFORD, 2004). It has a narrow natural distribution in southern wheatbelt and subcoastal areas of Western Australia at an elevation of 50-300 $\mathrm{m}$ and occupies a wide variety of habitats, from riparian areas, including swamps and salt lakes, to xeric landscapes (CHIPPENDALE, 1973; BROOKER and KLEINIG, 1990). This species has moderate to high tolerance to salt and waterlogging (PEPPER and CRAIG, 1986; MARCAR et al., 1995, 2003; BENYON et al., 1999) and there is interest in planting E. occidentalis for rehabilitation and reclamation of saline areas especially for agricultural land suffering from waterlogging and increasing dryland salinity. Eucalyptus occidentalis was selected as one of six species for tree improvement by the Australian Low Rainfall Tree Improvement Group (HARWOOD et al., 2001). Thus, genetic improvement of salt tolerance in 
$E$. occidentalis would facilitate its deployment as a suitable plant for management of saline agricultural land in southern Australia.

Previous screening of an E. occidentalis breeding population of 30 families from nine provenances for salt and/or waterlogging tolerance (up to $550 \mathrm{mM} \mathrm{NaCl}$ ) resulted in differential response for growth and survival (HENDRATI, 2008). Breeding among these families will be undertaken and this may be facilitated by knowledge of genetic diversity within the provenances and families to avoid the possibility of inbreeding depression in the future. Analysis of genetic diversity in natural populations of $E$. occidentalis using RFLP markers indicated a moderate level of genetic diversity with no evidence of inbreeding and little differentiation among populations (ELLIOTT and BYRNE, 2003). Microsatellite markers detect high levels of diversity in eucalypts (BYRNE, 2008) and are thus useful for assessing genetic diversity between parents in a breeding population.

The objective of this study was to assess genetic diversity among 30 families selected from nine provenances in $E$. occidentalis and to examine the heritability and effect of genetic distance between parental individuals on the performance of progeny under salt/waterlogged conditions. Controlled crossing with the immature style 'one stop pollination' method was used to produce progeny from selected $E$. occidentalis parents for evaluation of performance under salt/waterlogging conditions. The effect of parental genetic distance, assessed using microsatellites, on seed production and early seedling survival was examined and inheritance of salt waterlogging tolerance was assessed by testing performance of progeny in comparison to parents.

\section{Materials and Methods}

\section{Plant material}

A previous salt and waterlogging screening trial where salt concentration was increased to sea salt level (550 $\mathrm{mM}$ ), held for 2 weeks and slowly reduced to $0 \mathrm{mM}$ salt over 4 weeks resulted in survival of 310 seedling individuals of 30 families from nine provenances of E. occidentalis (Beaufort River, Gordon, Grass Patch, Katanning, Lake Magenta, Red Lake Siding, Stirling Range, Truslove and Young River). For this study, these plants were potted out and assessed for genetic diversity. Plants that flowered at 22 months were used as parents in controlled crosses in low $\mathrm{x}$ low, high $\mathrm{x}$ low and high $\mathrm{x}$ high salt tolerance combinations to produce progeny that were then screened for salt waterlogging tolerance. However, very few individuals survived within low $\mathrm{x}$ low crosses so these were not assessed further.

\section{Genetic analysis}

Genomic DNA was extracted from leaves of the plants following a CTAB protocol for large scale DNA extraction (BYRNE et al. 1998). DNA concentration was assessed using a low range assay solution (10-500 $\mathrm{ng} / \mathrm{\mu L}$ ) in a Fluorometer DyNA Quantum 200 (Pharmacia Biotech, Hoefer, San Francisco, USA) and samples were diluted to $20 \mathrm{ng} / \mu \mathrm{L}$. Nuclear microsatellite loci for eucalypts (En 6, 10 and 16; EMBRA 2-19; EMCRC 1a, 6, 12; BYRNE et al. 1996; RONDANI et al. 1998; STEANE et al. 2001) were tested for amplification and polymorphism in the 310 selections. DNA template (30 ng) was amplified through PCR in a final volume of $15 \mu \mathrm{L}$, containing $50 \mathrm{mM}$ KCl, 20mM Tris $\mathrm{HCl} \mathrm{pH} 8.4,0.2 \mathrm{mM}$ each dNTP, $0.3 \mu \mathrm{M}$ of each primer, $1.5 \mathrm{mM} \mathrm{MgCl} 2$ and 0.5 units of Taq DNA polymerase (Life Technologies Invitrogen). PCR was performed in a Bio-Rad thermocycler (London, UK) with a denaturing step at $96^{\circ} \mathrm{C}$ for 2 min followed by 30 cycles of $95^{\circ} \mathrm{C}, 56^{\circ} \mathrm{C}, 72^{\circ} \mathrm{C}$ for 30 seconds at each step and one final cycle of $72^{\circ} \mathrm{C}$ for $5 \mathrm{~min}$. PCR products were size-fractionated and visualized by fluorescence in an ABI 3730 automated capillary sequencer using Genescan-500 LIZ size standard.

Eight primers that revealed interpretable polymorphisms were selected for further analysis of E. occidentalis (EMBRA 3, 5, 8, 11, 17, En 6, EMCRC 6, 12). The number of alleles, and observed and expected heterozygosity ( $\mathrm{Ho}$ and $\mathrm{He}$ respectively) were calculated for each provenance and family using Powermarker (LIU and Muse, 2005). Relationships between geographic (altitude, longitude $\left({ }^{\circ} \mathrm{E}\right)$ ) or climatic variables (annual rainfall $(\mathrm{mm})$ ) and genetic diversity $(\mathrm{He})$ were investigated using ordinary linear regression analysis of untransformed data. Genetic distances between individuals were determined according to GoLDSTEIN et al. (1995) using a stepwise mutation model as this is suitable for microsatellite data (LOWE et al. 2004). Relationships among individuals based on genetic distance were determined using the Unweighted Pair Group Method with Arithmetic mean (UPGMA) using POWERMARKER v3.25.

\section{Controlled crosses}

The seedlings that survived the original salt/waterlogging treatment were transplanted into potting mix (Premium P/CM, Baileys Fertilizers, Perth) in $15 \mathrm{~cm}$ diameter pots. Complete element NPK Blue fertilizer at 0.5 gram/pot $(\mathrm{N}=12 \%, \mathrm{P}=5.2 \%, \mathrm{~K}=14.1 \%, \mathrm{~S}=7 \%, \mathrm{Ca}=$ $3.5 \%, \mathrm{Mg}=1.2 \%, \mathrm{Fe}=0.1 \%, \mathrm{Zn}=0.01 \%$ and $\mathrm{Bo}=0.02 \%$, Baileys, Western Australia) was added at 3 months to stimulate plant growth. Plants were arranged under a 16-h light/8-h dark regime. Families of seedlings were classified as high, medium or low salt tolerance based on the combined trait values from each individual (survival, height, relative growth and leaf number) in the original salt/waterlogging treatment. A total of 102 plants initiated flowers at 22 months old.

Controlled crosses were carried out for 45 combinations of high $\mathrm{x}$ high, high $\mathrm{x}$ low and low $\mathrm{x}$ low salt tolerance, with at least 3 individual flowers per plant per cross. Pollen was collected from flower buds (male parents) with yellowish and/or lifted, but attached opercula to ensure pollen was not contaminated. Anthers were trimmed, dried using silica gel and stored in sealed petri dishes at $-20^{\circ} \mathrm{C}$ (0-15 days) for use when female parent flowers were ready for pollination. Pollen was thawed for $1 \mathrm{~h}$ before pollination. Pollination followed the 'onestop pollination' technique of HARBARD et al. (1999). This method had not been used previously in E. occidentalis, but was expected to be suitable for maximizing the seed 
Table 1. - Details of families of Eucalyptus occidentalis used to assess parental and progeny performance under controlled and salt-waterlogged (500 $\mathrm{mM}$ salt) conditions. Seedling progeny of five check-families and eight controlled crosses (A-H) were tested.

\begin{tabular}{|c|c|c|c|c|c|c|}
\hline Treatment & $\begin{array}{l}\text { Family or cross } \\
\text { combination }\end{array}$ & $\begin{array}{c}\text { Family of female } \\
\text { parent }\end{array}$ & $\begin{array}{c}\text { Family of male } \\
\text { Parent }\end{array}$ & $\begin{array}{c}\text { Salt } \\
\text { tolerance } \\
\text { of female }\end{array}$ & $\begin{array}{c}\text { Salt } \\
\text { tolerance } \\
\text { of male }\end{array}$ & $\begin{array}{c}\text { No. of } \\
\text { seedlings }\end{array}$ \\
\hline $\mathrm{C}$ & 87-Beaufort & - & - & & & 14 \\
\hline $\mathrm{C}$ & 136-Grass $P$ & - & - & & & 7 \\
\hline C & 149-Red Lake & - & - & & & 15 \\
\hline C & 151-Red Lake & - & - & & & 15 \\
\hline C & 153-Red Lake & - & - & & & 13 \\
\hline $\mathrm{C}$ & A & 36-Katanning & 124-Red Lake & Low & High & 10 \\
\hline $\mathrm{C}$ & $\mathrm{B}$ & 96-L Magenta & 20-Young & Low & High & 10 \\
\hline$c$ & C & 110-Young & 108-Young & High & High & 3 \\
\hline SW & 87-Beaufort & - & - & & & 14 \\
\hline SW & 136-Grass P & - & - & & & 7 \\
\hline SW & 149-Red Lake & - & - & & & 15 \\
\hline SW & 151-Red Lake & - & - & & & 15 \\
\hline SW & 153-Red Lake & - & - & & & 13 \\
\hline SW & A & 36-Katanning & 124-Red Lake & Low & High & 20 \\
\hline SW & $\mathrm{B}$ & 96-L Magenta & 20-Young & Low & High & 20 \\
\hline SW & $\mathrm{C}$ & 110-Young & 108-Young & High & High & 4 \\
\hline SW & D & 20-Young & 30-Katanning & High & Low & 3 \\
\hline SW & $E$ & 20-Young & 96-L Magenta & High & Low & 4 \\
\hline SW & $\mathrm{F}$ & 110-Young & 150-Red Lake & High & Low & 3 \\
\hline SW & $G$ & 96-L Magenta & 76-Truslove & Low & High & 5 \\
\hline SW & $\mathrm{H}$ & 76-Truslove & 124-Red Lake & High & High & 5 \\
\hline
\end{tabular}

$\mathrm{C}=$ control, $\mathrm{SW}=$ salt-waterlogging.

Note: Low x Low crosses did not produce surviving seedlings for tolerance testing.

output of the limited number of available flowers and parents to produce as many progeny seeds as possible.

Capsules were harvested at 9 months after pollination and air dried to extract seeds. Seeds were germinated and potted out for salt tolerance testing. Capsule production, seed production and seedling survival were calculated for each cross and correlated with parental genetic distance ordinary linear regression analysis of untransformed data.

\section{Salt tolerance test}

Progeny from controlled crosses (Table 1) were grown to 9.5 months then exposed to salt-waterlogged conditions. Progeny from three crosses (A, B and C) were included as controls and progeny from five 9.5-month old families used in the salt screening of the original parent trees were included as check-families to compare both testing environments and to adjust the progeny performance.

A total of 215 seedlings from the five control families and the progeny of eight crosses were randomly placed in two separate tanks (from Oct 2007 to Jan 2008), control (drained) and salt/waterlogging (treatment), with 35 replicates per tank, prior to addition of salt to allow for plants to acclimatize. The control tank pump was set for $30 \mathrm{~min}$ watering ( $3 \mathrm{x}$ daily) to bring water levels up to $1 \mathrm{~cm}$ below the potting media, and then allowed to drain. In the other tank salt solutions were replaced weekly and salt concentration was increased in equal weekly increments $(50 \mathrm{mM})$ up to $500 \mathrm{mM} \mathrm{NaCl}$. The salt solution was at a ratio of $\mathrm{NaCl}: \mathrm{CaCl}_{2}=14: 1$, to equate to natural calcium content (CRAIG et al., 1990;
VAN DER MoEzel et al., 1991). The fertilizer used was a half concentration of complete hydroponics nutrients (Three Part Perfection, Wanneroo, WA).

Plant survival was recorded every week. Height of seedlings were measured in the second week (before salt was applied), at 5 weeks ( $250 \mathrm{mM}$ salt) and at 11 weeks (500 mM salt). Relative growth was calculated between 1 week and 11 weeks (( height 11 at weeks- height at 1 week/height at 1 week $))+100 \%)$. All leaves were marked and counted to differentiate new from old leaves. Height data from the 5 check-families were correlated with data from the original experiment to assess similarity of environments and analyzed using two wayANOVA in Excel. Data for progeny were adjusted using check-families. Mid-parent performance under the first screening experiment were compared to progeny performance under the salt tolerance test. Heritability was assessed using parent-progeny correlation instead of parent-progeny regression due to the potentially different testing environments (Bos and CALIGARI, 1995). Analysis of survival could not be carried out because of the limited material. A one-tailed t-test was used to compare progeny mean height with genetic distance between parents for different crosses.

\section{Results \\ Genetic diversity}

A high level of genetic diversity was evident among the original nine provenances using the eight selected microsatellite loci, and all loci were polymorphic (Table 2 ). The number of alleles per locus ranged from 17 (En6) 
Table 2. - Genetic diversity parameters of Eucalyptus occidentalis families from nine provenances. Na, average number of alleles per locus. $P$, proportion of polymorphic loci. Ho, observed heterozygosity. He, expected heterozygosity. $F_{I S}$, fixation index. s.e., standard error.

\begin{tabular}{lccccccc}
\hline \multicolumn{1}{c}{ Provenance } & $\begin{array}{c}\text { No. } \\
\text { individuals }\end{array}$ & $\begin{array}{c}\text { No. } \\
\text { families }\end{array}$ & $\mathrm{Na}(\mathrm{s.e})$ & $\begin{array}{c}P \\
(\%)\end{array}$ & $H o(\mathrm{~s} . \mathrm{e})$ & $\mathrm{He}(\mathrm{s.e.})$ & Fis (s.e.) \\
\hline Beaufort & 47 & 5 & $16.5(0.334)$ & 100 & $0.526(0.009)$ & $0.838(0.003)$ & $0.398(0.009)$ \\
Gordon & 9 & 1 & $7.0(0.248)$ & 100 & $0.474(0.033)$ & $0.717(0.008)$ & $0.451(0.034)$ \\
Grass Patch & 38 & 3 & $12.6(0.168)$ & 100 & $0.471(0.008)$ & $0.765(0.005)$ & $0.412(0.009)$ \\
Katanning & 40 & 3 & $16.5(0.207)$ & 100 & $0.553(0.001)$ & $0.859(0.002)$ & $0.381(0.011)$ \\
L. Magenta & 22 & 2 & $10.4(0.176)$ & 100 & $0.512(0.011)$ & $0.776(0.004)$ & $0.372(0.017)$ \\
Red Lake Siding & 82 & 8 & $17.6(0.148)$ & 100 & $0.474(0.005)$ & $0.842(0.003)$ & $0.448(0.004)$ \\
Stirling & 15 & 2 & $9.3(0.280)$ & 100 & $0.431(0.016)$ & $0.741(0.006)$ & $0.478(0.017)$ \\
Truslove & 16 & 1 & $8.3(0.203)$ & 100 & $0.538(0.013)$ & $0.706(0.008)$ & $0.282(0.020$ \\
Young River & 45 & 5 & $17.5(0.247)$ & 100 & $0.496(0.008)$ & $0.820(0.004)$ & $0.412(0.008)$ \\
\hline
\end{tabular}

to 55 (EMCRC6). The maximum number of alleles across all loci in a provenance was 26 . The mean number of alleles per locus ( $\mathrm{Na}$; Table 2) was high but varied among provenances relative to sample size so comparisons among provenances cannot be made. Across provenances, the number of rare alleles (frequency $<0.1$ ) was very high $(72 \%)$, while the number of common alleles (frequency $>0.5$ ) was very low $(2.5 \%)$. Observed heterozygosity $\left(H_{o}\right)$ and expected Hardy-Weinberg panmictic heterozygosity $\left(H_{e}\right)$ were moderate and were generally similar in all provenances. The inbreeding coefficient $\left(F_{I S}\right)$ was high, as expected, due to the assessment of families rather than unrelated individuals (Table 2).

Allelic diversity in families was generally high and the maximum number of alleles per locus in any one family was 12 . Across families, there were a similar proportion of rare alleles $(50 \%)$ and common alleles $(49 \%)$. The number of individuals per family ranged from 4 to 17 and mean number of alleles per family was generally associated with family size. $H_{o}$ and $H_{e}$ were moderate to high and had values between $0.563-0.695$ and 0.395-0.768, respectively. Highest allelic diversity ( $>0.683$ ) occurred in some families from the northern range of the natural distribution including all families from Katanning, three families from Red Lake Siding (122, 124 and 153), two families from Beaufort River (86 and 87), and one family from each of Young (108), Lake Magenta (94) and Grass Patch (137). Most of the diversity was distributed within $(84 \%)$ rather than between families $(16 \%)$. Families from the two eastern provenances that originate from calcareous areas, Red Lake Siding and Grass Patch, possessed 37\% of the diversity. Overall there were only weak correlations between family genetic diversity and geographic parameters, such as longitude, where there was more diversity in the west (Family $\mathrm{H}_{\mathrm{e}}=-11.1 \mathrm{x}$ longitude $+127, \mathrm{R}^{2}=0.121$, $\mathrm{p}<0.5)$ and with increasing altitude $\left(\right.$ Family $\mathrm{H}_{\mathrm{e}}=245 \mathrm{x}$ altitude $\left.+81, \mathrm{R}^{2}=0.108, \mathrm{p}<0.5\right)$ or climatic variables where increasing annual rainfall was associated with greater diversity (Family $\mathrm{H}_{\mathrm{e}}=233 \mathrm{x}$ rainfall +290 , $\mathrm{R}^{2}=0.032, \mathrm{p}>0.5$ ).

Analysis of the relationships between families showed little clustering of families from the same provenances

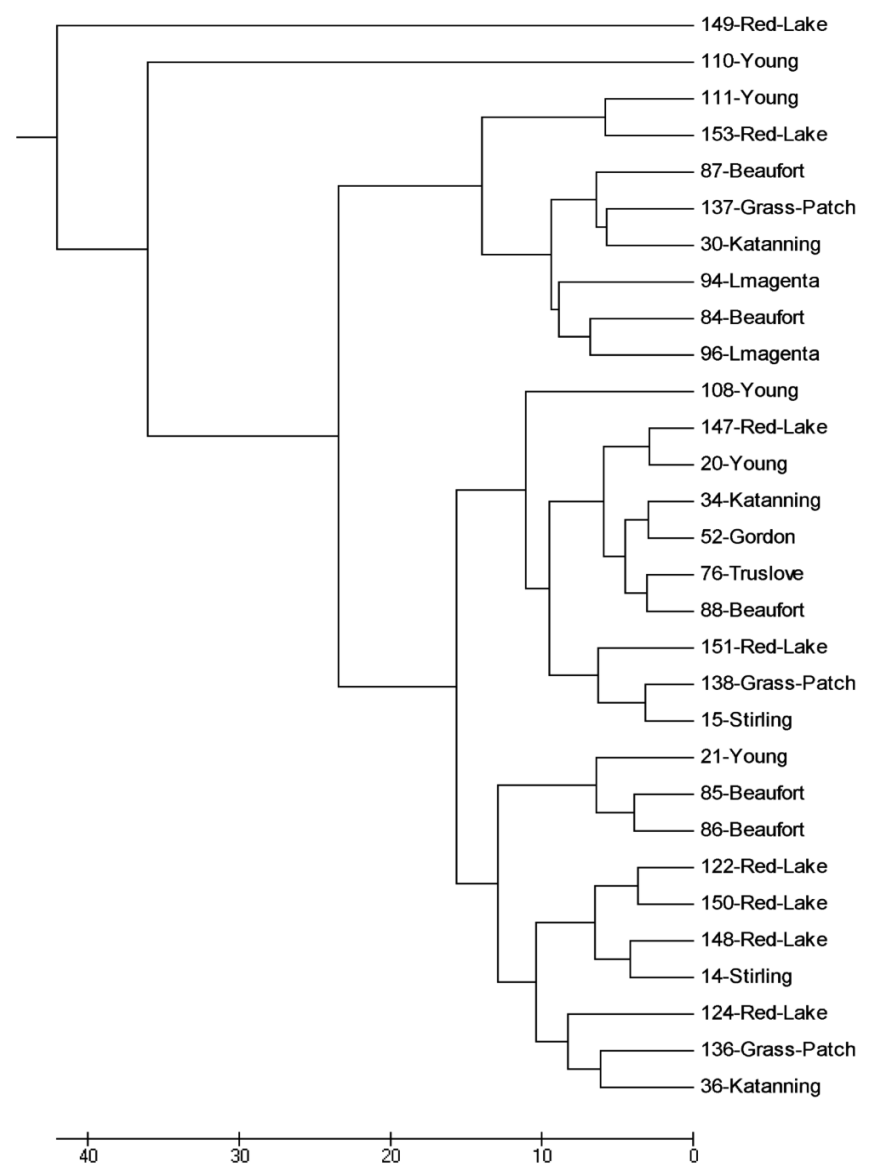

Figure 1. - Genetic relationship between families from nine provenances of Eucalyptus occidentalis based on Unweighted Pair Group Method with Arithmetic mean analysis of Goldstein's genetic distance. 
except for three families from Red Lake Siding (Figure 1). Two families, 149-Red Lake Siding and 110-Young, showed differentiation from the rest of the families.

\section{Controlled crosses}

Success of pollination in the 45 crosses was low and $8 \%$ of pollinated flowers involving 25 crosses produced capsules at harvest. Seed germination occurred for 22 crosses but early seedling mortality was high and only eight crosses produced seedlings that survived to 9 months (Table 3 ). There was a very weak but significant correlation $(\mathrm{p}=0.001)$ between capsule production and parental genetic distance (Figure $2 a$ ). There was a positive trend between increasing parental genetic distance and increasing number of germinated seeds/capsule, seedling survival at 2 weeks and at 9 months (Figure 2). When one outlier was excluded, association was greater $(\mathrm{R}=0.67, \mathrm{p}=0.001)$ for number of germinated seed per capsule and seedling survival at 2 weeks (Figure $2 B$ and $C$ ) but decreased for 9 month seedling survival.

Table 3. - Cross combinations of Eucalyptus occidentalis male and female parents, their pairwise genetic distances, number and proportion (\%) of germinating seeds/capsule, and number and proportion (\%) of seedlings surviving at 9 months.

\begin{tabular}{|c|c|c|c|c|c|c|c|}
\hline $\begin{array}{l}\text { Female family } \\
\text { provenance }\end{array}$ & $\begin{array}{l}\text { Male family } \\
\text { provenance }\end{array}$ & $\begin{array}{l}\text { Cross } \\
\text { combination } \\
\text { (level of salt } \\
\text { tolerance) }\end{array}$ & $\begin{array}{l}\text { Individual } \\
\text { genetic } \\
\text { distance of } \\
\text { parents }\end{array}$ & $\begin{array}{l}\text { Family } \\
\text { genetic } \\
\text { distance of } \\
\text { parents }\end{array}$ & $\begin{array}{l}\text { Provenance } \\
\text { genetic } \\
\text { distance of } \\
\text { parents }\end{array}$ & $\begin{array}{c}\text { Germinated } \\
\text { seeds/ } \\
\text { capsule } \\
(\%)\end{array}$ & $\begin{array}{c}\text { Seedling } \\
\text { survival at } 9 \\
\text { months }(\%)\end{array}$ \\
\hline 36-Kat & 124-Red & $(\mathrm{L} \times \mathrm{H})$ & 7727 & 268 & 55 & 41 (68) & $30(50)$ \\
\hline 96-LMag & 20-Young & $(\mathrm{L} \times \mathrm{H})$ & 3437 & 371 & 106 & $59(96)$ & $38(62)$ \\
\hline 110 -Young & 108 -Young & $(\mathrm{H} \times \mathrm{H})$ & 83 & 568 & 0 & 11 (19) & 7 (12) \\
\hline 20 -Young & 30-Kat & $(\mathrm{H} \times \mathrm{L})$ & 2138 & 379.3 & 103 & 5 (10) & $3(6)$ \\
\hline 20 -Young & 96-LMag & $(\mathrm{H} \times \mathrm{L})$ & 5550 & 371 & 106 & $23(25)$ & $4 \quad(4)$ \\
\hline 110 -Young & 150-Red & $(H \times L)$ & 2187 & 242 & 46 & 7 (24) & 3 (10) \\
\hline 96-LMag & 76-Trus & $(\mathrm{L} \times \mathrm{H})$ & 6145 & 159 & 97 & 7 (23) & $5 \quad(16)$ \\
\hline 76-Trus & 124-Red & $(\mathrm{H} \times \mathrm{H})$ & 4904 & 245 & 97 & $10(10)$ & 5 (5) \\
\hline
\end{tabular}

Young = Young river, LMag = Lake Magenta, Kat = Katanning, Red = Red Lake Siding, Trus = Truslove, H = High, $\mathrm{L}=$ Low salt and waterlogging tolerance.
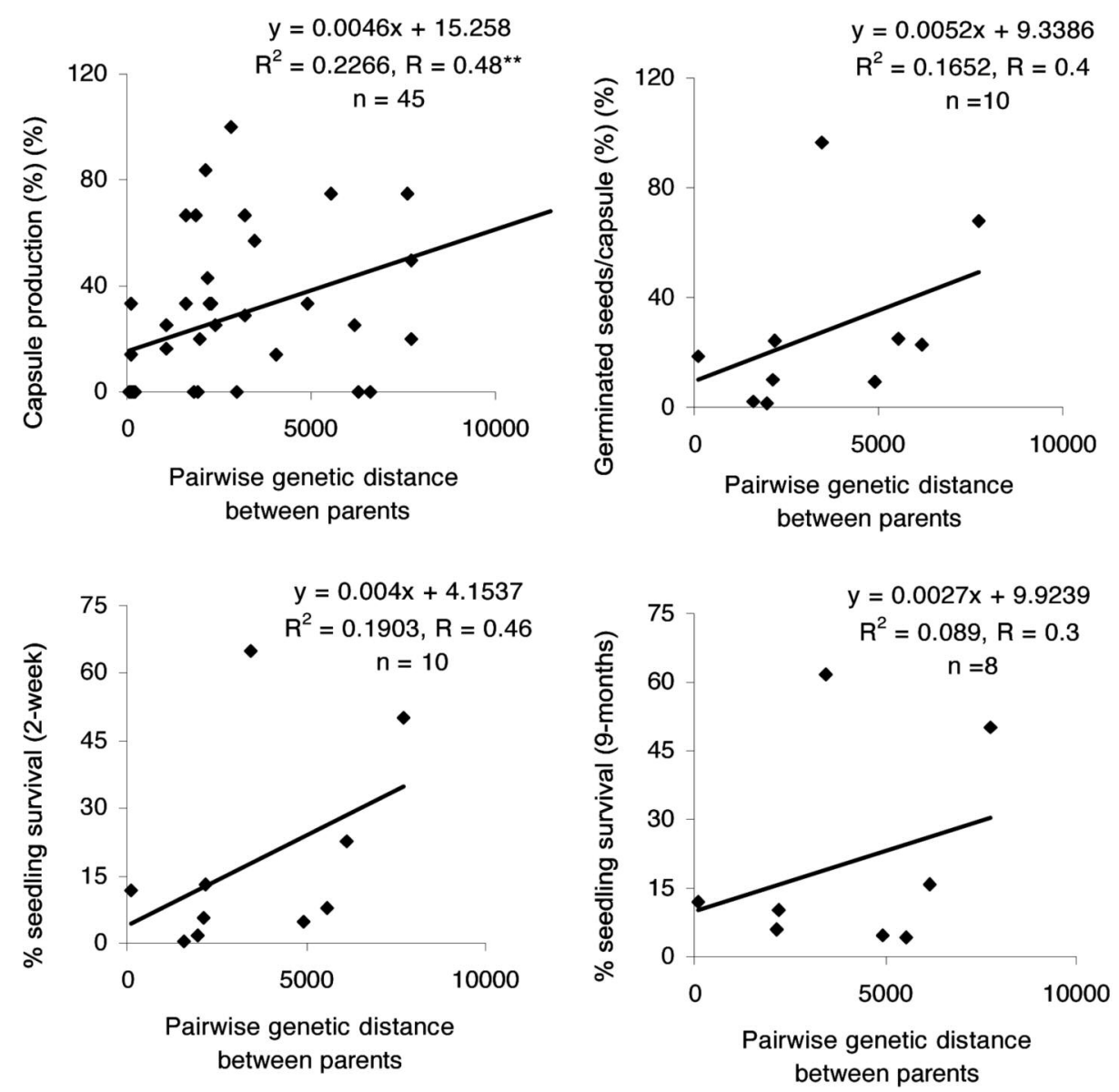

Figure 2. - Relationship between genetic distances between Eucalyptus occidentalis parents and fitness traits. (a) capsule production; (b) germinated seeds/capsule; (c) seedling survival at 2 weeks; (d) seedling survival at 9 months. ${ }^{* *} \mathrm{p}=0.001$. 

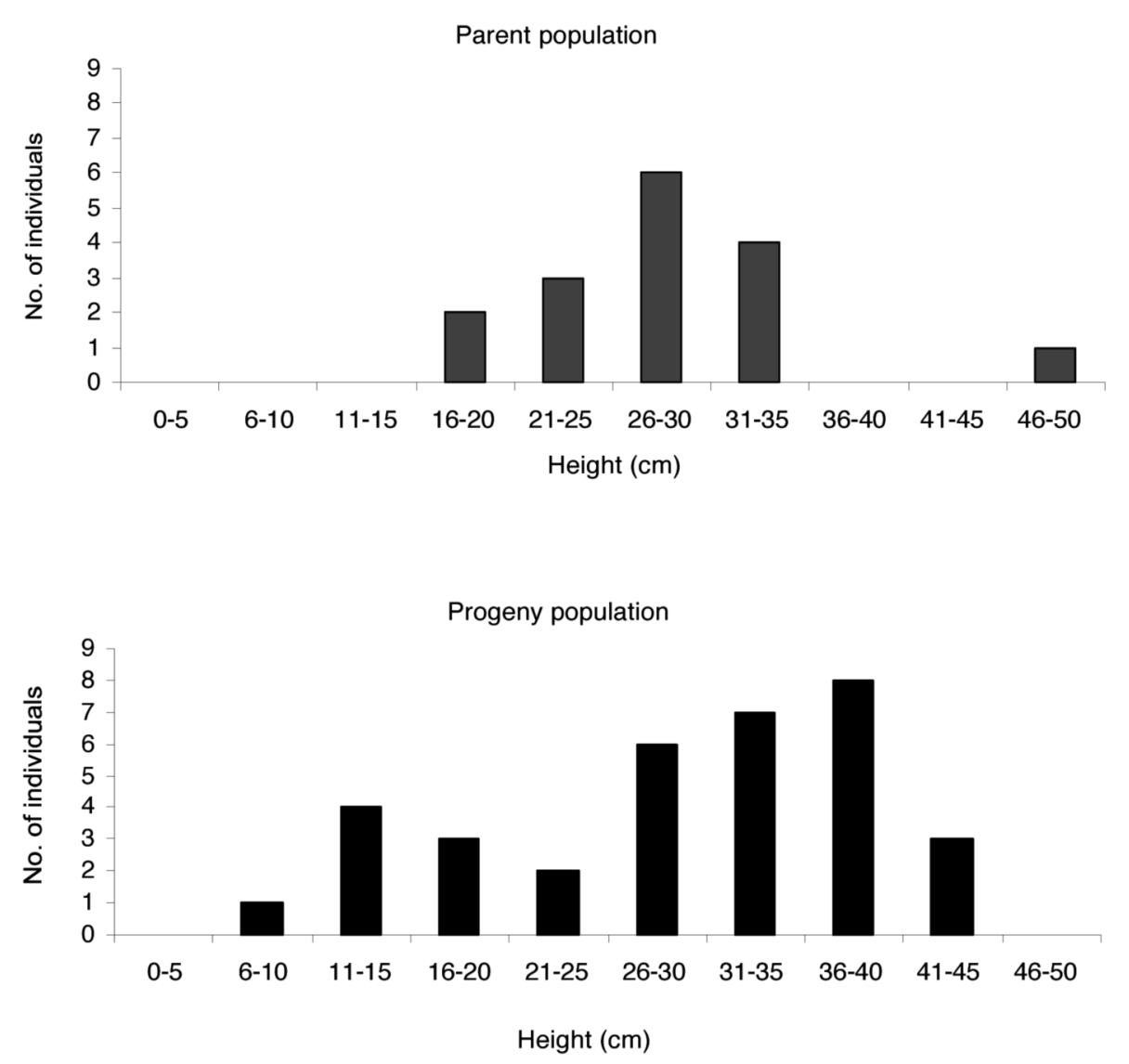

Figure 3. - Comparison of height in E. occidentalis parent and progeny populations under $500 \mathrm{mM} \mathrm{NaCl}$ treatment.

Table 4. - Survival, height, relative growth and final leaf proportion for eight Eucalyptus occidentalis crosses $(\mathrm{A}-\mathrm{H})$ under salt-waterlogged $(500 \mathrm{mM}$ salt) conditions. Analysis of variance was carried out for crosses with $\geq 3$ progeny to determine significance of differences among crosses for each trait. For cross combination details refer to Table 3 .

\begin{tabular}{|c|c|c|c|c|c|c|c|c|c|}
\hline & \multirow[b]{2}{*}{ Isd $^{\#}$} & \multicolumn{8}{|c|}{ Cross (no. progeny) } \\
\hline & & $\begin{array}{c}A \\
(9)\end{array}$ & $\begin{array}{c}B \\
(9) \\
\end{array}$ & $\begin{array}{c}C \\
(2) \\
\end{array}$ & $\begin{array}{c}\mathrm{D} \\
(1)\end{array}$ & $\begin{array}{c}E \\
(3)\end{array}$ & $\begin{array}{c}F \\
(1)\end{array}$ & $\begin{array}{c}G \\
(5)\end{array}$ & $\begin{array}{c}\mathrm{H} \\
(4) \\
\end{array}$ \\
\hline Survival (\%) & & 45 & 45 & 50 & 33 & 75 & 33 & 100 & 80 \\
\hline Height $(\mathrm{cm}){ }^{\star \star}$ & 8 & 36 & 28 & 30 & 12 & 21 & 28 & 30 & 27 \\
\hline 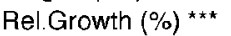 & 55 & 179 & 230 & 170 & 303 & 248 & 137 & 205 & 249 \\
\hline Final.Leaf $(\%)^{*}$ & 26 & 131 & 167 & 114 & 150 & 121 & 109 & 126 & 90 \\
\hline
\end{tabular}

\# lsd = least significant difference; significance of differences among crosses given.

${ }^{*}=(\mathrm{p} \mathrm{0.05}),{ }^{* *}=(\mathrm{P} 0.01),{ }^{* * *}=(\mathrm{P}<0.01)$.

\section{Salt tolerance assessment}

Five check-families were used to compare the two environments of the first screening experiment, where the performance of the parental trees was determined and the progeny test conducted here. There was a significant correlation between the mean heights of the five check-families in both experiments for the control treatment $\left(R^{2}=0.82\right)$ and for the salt waterlogging treatment $\left(\mathrm{R}^{2}=0.98\right)$ indicating that both test environments of the two experiments were similar. Comparison of families subjected to both the control and salt/waterlogging treatments showed differences indicating an effect of the salt treatment on survival and growth. Progeny under the $250 \mathrm{mM}$ salt treatment were shorter than those under the control treatment and the observed difference were even greater at $500 \mathrm{mM} \mathrm{NaCl}$.

Heritability values, under $500 \mathrm{mM}$ salt-waterlogging treatment, indicated that height was the only trait with moderate heritability $\left(h^{2}=0.5 \pm 3.4\right)$. Relative growth $\left(h^{2}=0.17 \pm 0.47\right)$ and final leaf proportion $\left(h^{2}=0.05 \pm 20.6\right)$ had low heritability values. It was not possible to compare heritability values across cross combinations between high $\mathrm{x}$ high, high $\mathrm{x}$ low and low $\mathrm{x}$ low because of the limited number of progeny from each combination, particularly in the low $\mathrm{x}$ low crossings where very few seedlings survived for further salt test- 
ing. Although not significant, overall there was an increase in mean height across the progeny population $(29.4 \pm 1.7 \mathrm{~cm}, \mathrm{n}=34)$ than in the parents $(28 \pm 1.7 \mathrm{~cm}$, $\mathrm{n}=16$ ) under $500 \mathrm{mM}$ salt-waterlogging treatment (Figure 3). The distribution of the progeny population was shifted towards the right (taller) compared with the parental population.

Comparison of performance of progeny of the different crosses showed that those with greater genetic distance between parents had greater survival and taller progeny. Only cross combinations with a parental genetic distance of $\geq 3436$ (A, B, E, G and $\mathrm{H}$ ) had $\geq 3$ surviving progeny under $500 \mathrm{mM}$ salt (Table 4, Figure 4). Cross combinations with parental genetic distance of $\geq 4904$ (E, $\mathrm{G}$ and $\mathrm{H}$ ) had $\geq 75 \%$ survival except cross combination A which had only $45 \%$ survival. Interactions between treatments and cross combinations were limited and influenced different aspects of growth. At 250 $\mathrm{mM}$ salt, cross combinations did not influence height, relative growth or final leaf proportion (data not shown). At $500 \mathrm{mM}$ salt comparisons of cross combinations showed that $\mathrm{A}(\mathrm{LxH}), \mathrm{C}(\mathrm{HxH})$ and $\mathrm{G}(\mathrm{LxH})$ were taller; $\mathrm{D}(\mathrm{HxL})$ and $\mathrm{H}(\mathrm{HxH})$ had greater relative growth; and
$\mathrm{B}(\mathrm{LxH})$ and $\mathrm{D}$ produced or retained more leaves than other crosses (Table 4).

A one-tailed t-test analysis revealed consistent patterns in comparison of progeny performance from crosses with $\geq 3$ individuals (Table 5). Progeny from crosses with similar parental genetic distance were similar in height. However, progeny from parents of medium genetic distance were shorter than progeny from parents with large genetic distances (B vs $\mathrm{A}$ and $\mathrm{E}$ vs $\mathrm{A}$ ). Compared to other crosses, Cross A between parents with the widest genetic distance (7727) produced the highest number of progeny with the greatest increase in height $(50 \%)$ from mid-range parents.

\section{Discussion}

\section{Genetic diversity}

Maintenance of genetic diversity in breeding populations is essential to avoid deleterious effects of inbreeding that are common in EUCALYPTUS (POTTS and WILTSHIRE, 1997; HARDNER and TIBBITS, 1998). This study has shown that high diversity can be maintained in a breeding population of $E$. occidentalis through selection from

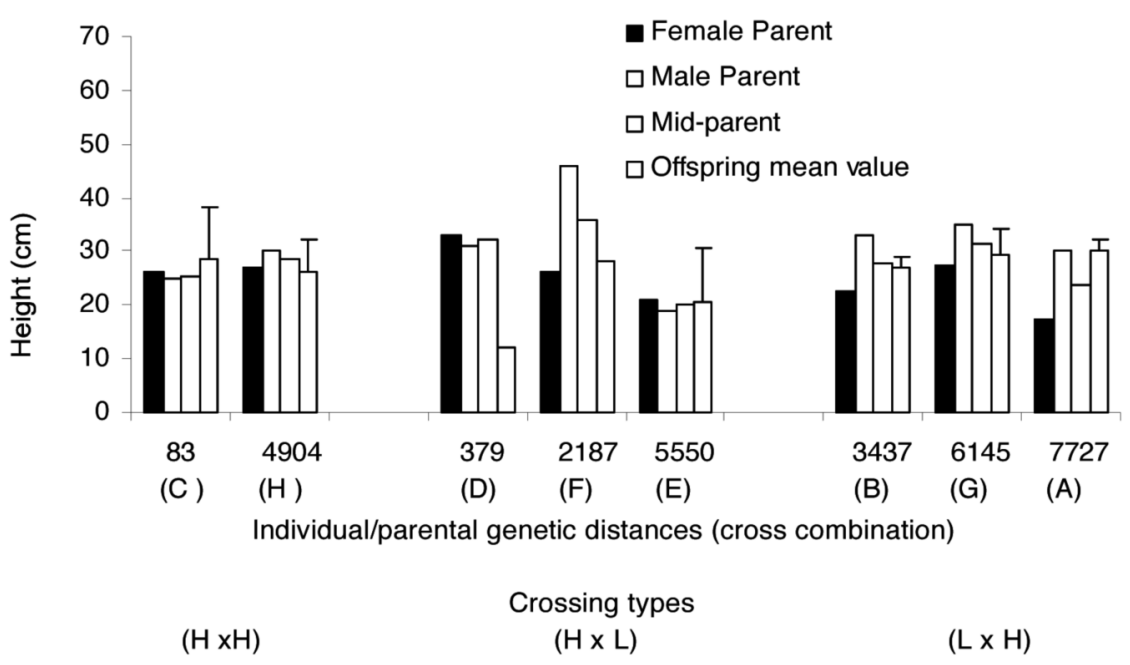

Figure 4. - Performance for height of parents and progeny of crosses of E. occidentalis. Performance was tested under $500 \mathrm{mM} \mathrm{NaCl}$ treatment for crosses with different genetic distance between parents and different slat tolerance of parents.

Table 5. - Comparison of mean-progeny height (t-test) from Eucalyptus occidentalis crosses between parents of different genetic distances. For cross combination details refer to Table 3 .

\begin{tabular}{|c|c|c|c|c|c|c|}
\hline \multirow[b]{2}{*}{$\begin{array}{c}\text { Cross } \\
1\end{array}$} & \multirow[b]{2}{*}{$\begin{array}{c}\text { Cross } \\
2\end{array}$} & \multicolumn{2}{|c|}{ Progeny height } & \multirow{2}{*}{$\begin{array}{c}\text { No.of } \\
\text { Progeny } \\
\text { cross } 1 / \text { cross } 2\end{array}$} & \multirow[b]{2}{*}{ Genetic distance } & \multirow{2}{*}{$\begin{array}{c}\mathrm{t} \text { test } \\
(\mathrm{P} 0.001)\end{array}$} \\
\hline & & $\begin{array}{c}\text { Cross } 1 \\
\text { (Mean } \pm \text { s.e) }\end{array}$ & $\begin{array}{c}\text { Cross } 2 \\
\text { (Mean } \pm \text { s.e) }\end{array}$ & & & \\
\hline$E$ & $\mathbf{H}$ & $21 \pm 6$ & $27 \pm 6$ & $3 / 4$ & $\begin{array}{l}\text { medium - medium } \\
5550 \text { and } 4904 \\
\text { medium - medium }\end{array}$ & ns \\
\hline$E$ & $\mathrm{~B}$ & $21 \pm 6$ & $28 \pm 2$ & $3 / 9$ & $\begin{array}{l}5550 \text { and } 3437 \\
\text { medium }- \text { medium }\end{array}$ & ns \\
\hline$E$ & $\mathrm{G}$ & $21 \pm 6$ & $30 \pm 5$ & $3 / 5$ & $\begin{array}{l}5550 \text { and } 6145 \\
\text { medium vs large }\end{array}$ & ns \\
\hline $\mathrm{B}$ & A & $28 \pm 2$ & $36 \pm 2$ & $9 / 9$ & $\begin{array}{l}3437 \text { and } 7727 \\
\text { medium vs large - }\end{array}$ & ** \\
\hline E & A & $21 \pm 6$ & $36 \pm 2$ & $3 / 9$ & $\begin{array}{c}5550 \text { and } 7727 \\
\text { large - large }\end{array}$ & $\star \star$ \\
\hline $\mathrm{G}$ & A & $30 \pm 5$ & $36 \pm 2$ & $5 / 9$ & 6145 and 7727 & ns \\
\hline
\end{tabular}

$\mathrm{ns}=$ not significant; ${ }^{* *}=(\mathrm{P}<0.01)$. 
a representative range of provenances in the species distribution. This is similar to the high level of diversity maintained in first generation selections of $E$. globulus (JONES et al., 2006) and clonal orchards of E. dunii (MARCUCCI Poltri et al., 2003). Maintenance of high diversity in breeding populations in eucalypts is likely to be related to the high diversity generally found in most eucalypt species (BYRNE, 2008). A previous assessment of genetic diversity in the natural populations of $E$. occidentalis found moderate levels of diversity consistent with its localised distribution (ELLIOTT and BYRNE, 2003). The diversity found in this study was higher than that of the natural populations due to the different marker systems used in the two analyses, RFLP analysis in ELLIOTT and BYRNE, (2003) versus microsatellites in this study. Comparison of diversity in different markers systems in eucalypts has shown a general pattern of a two-fold increase in measured levels of diversity with microsatellite markers compared to RFLPs (BYRNE, 2008) as was detected here.

High genetic diversity is influenced by the proportion of rare alleles. Inclusion and maintenance of rare alleles in a breeding program is important especially as these alleles may be related to beneficial genes (YANCHUK, 2001). The frequency of rare alleles was high in the families of $E$. occidentalis assessed here indicating that sufficient genetic diversity has been retained in these families for future breeding purposes. Maintenance of diversity even though families were selected from only nine provenances will be related to the low level of genetic differentiation between provenances across the natural distribution of $E$. occidentalis (ELLIOTT and BYRNE, 2003).

Although differentiation among provenances was low there was some correlation between genetic diversity and environmental factors, with higher diversity associated with lower longitude (west) and higher altitude (longitude and altitude were not related). Association of higher diversity with high elevation is consistent with trends in the natural populations (ELLIOTT and BYRNE, 2003). There is a greater occurrence of salinity and waterlogging in lower elevation areas in south-western Australia (HUNT and GILKES, 1992) and lower diversity in $E$. occidentalis from low elevation sites, where they would be exposed to salinity and waterlogging stresses, may be an indication of some adaptation and selection in these saline environments. This is supported by the better performance in the salt and waterlogging trials of families from the two provenances from the most saline environments, Red Lake Siding and Grass Patch. Good performance of families from Grass Patch has also been observed in earlier trials in Australia and Italy (HARWOOD et al., 2001). These provenances may also have advantages in terms of stress tolerance associated with soil characteristics. There were substantial differences in soil characters between the eastern provenances, that grew on calcareous sands (containing calcium carbonate or lime), and most other provenances that grew on various soils including low nutrient soils derived from the Yalgarin block, loams, clays and duplex soils, some with periodic waterlogging (CONACHER and CONACHER, 1998). Soil with calcium carbonate tends to be alkaline and nutrient availability is limited due to lack of solubility of many elements under high $\mathrm{pH}$ (HuNT and GILKES, 1992). The eastern provenances of $E$. occidentalis may have natural adaptation to high $\mathrm{pH}$ and/or low nutrient availability. This requires further examination, but nonetheless it would be a useful adaptation for production in much of the south west of Western Australia, and in other low nutrient or alkaline soils, such as those found in the eastern Mediterranean (ZOHAR, 1991).

Genetic relationships among families were essentially random and showed no structure in relationship to provenance. This suggests that any adaptation to saline environments has not increased genetic similarity indicating that there would be little genetic constraint to further exploration of salt and waterlogging tolerance within the two best performing provenances, Red Lake Siding and Grass Patch. There is a strong possibility that different genes and perhaps different mechanisms are being employed for salt /and waterlogging tolerance and it may be possible to pyramid these traits (BENNET and KUSH, 2003). Low levels of genetic structuring imply that breeding with salt and waterlogging-tolerant individuals from these or other $E$. occidentalis provenances would be expected to result in substantial increases in salt and waterlogging tolerance, but no decline in genetic diversity.

The one stop pollination of immature styles (HARBARD et al., 1999) was suitable for controlled crossing in $E$. occidentalis although the numbers of fruit and seed produced were relatively low. This is most likely related to the young age of the parental plants as they were pollinated at first flowering. Low fruit production is common in young plants following the transition from the juvenile to mature stage as the apportioning of photoassimilates shifts (SEDGLEY and GRIFFIN, 1989). However, there was also evidence of a genetic effect in fruit production. Crosses between parents with small genetic distance had low capsule production, poor seed germination and early seedling death. This is likely to be an expression of inbreeding depression that is common in Eucalyptus (ELDRIDGE et al., 1994; HARDNER and PoTTS, 1995; SEDGLEY and GRIFFIN, 1989). Eucalyptus occidentalis has a high outcrossing rate under open pollination conditions (BYRNE, 2004) and low fitness is expected in crosses between related parents (WILLI and BUSKIRK, 2005). Expression of inbreeding depression has also been observed as reduced wood volume at 4 years of age in E. globulus (HARDNER et al., 1998). Molecular measurement of genetic distance and careful selection of parents would help to avoid this late effect on wood production in $E$. occidentalis. Further research will be required to determine the best provenances and families for salt and waterlogging tolerance breeding but certainly microsatellites provide a suitable means to screen parents for adequate genetic distance to avoid the deleterious effects of inbreeding in breeding programs.

\section{Salt and/waterlogging tolerance assessment}

Assessment of trait expression requires standardization of screening tests that give repeatable, consistent results. Factors that influence expression of salt-tolerance that need to be controlled in multiple assessments 
include salt concentration, macro and micro nutrient levels, timing, length of exposure, and environmental factors such as temperature, humidity, net radiation and potting media (SHANNON, 1997). In this study standardization of test environments was assessed by the inclusion of five check-families in both the original experiment and the analysis of progeny performance reported here. The performance under salt/waterlogged treatment of the parental and progeny populations was highly correlated indicating standardization of conditions. Thus repeated salt/waterlogged testing can be carried out for a species, such as E. occidentalis, with many provenances and families, when numbers are too large to be completed in one trial, or over subsequent generations as in this study, as long as control families are included to assess and confirm repeatability.

Determination and measurement of inherited traits is essential for assessment of trait expression. Both progeny and parents exposed to salt/waterlogging stress showed similarity in height, growth and final leaf proportion. However, only height had high heritability and this was supported by ANOVA-based (HENDRATI, 2008), and to a lesser extent parent-offspring regression, heritability values. Heritability values using analysis of variance are often higher than parent offspring regression (ZOBEL and TALBERT, 1984; Bos and CALIGARI, 1995). Here the differences in these tests may have been due to sampling as ANOVA-based analysis was derived from 237 data points from 30 families, while parent-offspring regression used 35 progeny from eight cross combinations. Low crossing success producing very few progeny reduces precision of heritability estimates (LOODINKINS, 1992). In addition, parent seedlings were selected for uniformity before screening, increasing the precision of heritability estimation, whereas variation in progeny performance was influenced by differences in seedling size due to irregular seedling emergence following germination (BURDON and SwEET, 1979). Controlled pollination of young plants may also have biased results as only individuals with flowers could be used and these were not necessarily the best performers.

Wide parental genetic distance increased progeny survival and performance under salt-waterlogging conditions in E. occidentalis. The mean survival and height of progeny were higher than their parental mean values and the overall mean value for the progeny population was increased compared to that of the parental population. Crosses with the widest parental genetic distance produced progeny with considerable height increase above parents and this trend was evident even with moderate genetic distance. Genetic fitness determines vigor, plant size and the ability to grow under saline conditions (Hu et al., 1977; MUNNs and TERMAAT, 1986) especially the harsh, salt-waterlogged conditions used in this study. Lower fitness of progeny from parents with close genetic distance was expected due to inbreeding depression resulting from increasing homozygosity and deleterious recessive alleles (CHARLESWORTH and Charlesworth, 1987). This reflects the strong association between genetic similarity of sexually mated parents and the performance of their progeny. However, the association is represented by a bell-shaped curve such that performance will be reduced once optimum genetic distance is exceeded. The greatest genetic distances examined here improved progeny performance and this may represent the intermediate genetic distance which achieves optimum fitness (WILLI and BUSKIRK, 2005). When genetic distance between parents is too wide, as in some wide intra-specific crosses and interspecific hybridizations, outbreeding depression can be expressed due to the disruption of local adaptation, underdominance or epistatic interactions, and the breakdown of coadapted gene complexes (EDMANDS, 2007). However, this end of the association was not explored in this study and further examination of crosses from wide genetic distances may be required to confirm that the optimum genetic distance for breeding in $E$. occidentalis has indeed been obtained. Genetic recombination in progeny may also have added value and this can be exploited in large crossing programs (ZOBEL and TALBERT, 1984).

\section{References}

Bennet, J. and G. S. Kush (2003): Enhancing salt tolerance in crops through molecular breeding: A new strategy, pp. 11-65. In: Crop production in saline environments: Global and integrative perspectives, edited by S. S. Goyal, S. K. Sharma and D. W. Rains, Haworth Press, London.

Benyon, R. G., N. E. Marcar, D. F. Crawford and A. T. NiCHOLSON (1999): Growth and water use of Eucalyptus camaldulensis and $E$. occidentalis on a saline discharge site near Wellington, NSW, Australia. Agricultural Water Management 39: 229-244.

Bos, I. and P. CALIGARI (1995): Selection methods in plant breeding, Chapman \& Hall, London.

Brondani, R. P. V., C. Brondani, R. Tarchini and D. GRATTAPAGLIA (1998): Development characterization and mapping of microsatellite markers in Eucalyptus grandis and Eucalyptus urophylla. Theoretical and Applied Genetics. 97: 816-827.

BrookeR, M. I. H. and D. A. KLeINIG (1990) Field guide to eucalypts. Volume 2 south-western and southern Australia. Inkata Press, Melbourne.

Burdon, R. D. and G. B. SweEt (1976): The problem of interpreting inherent differences in tree growth shortly after planting, pp. 483-502. In: Tree physiology and yield improvement, edited by M. G. R. CANNELL and F. T. LAST, Academic Press, London.

Byrne, M. (2008): Eucalyptus phylogeny, diversity and evolution, pp. 303-346. In: Plant genome: Biodiversity and evolution. 1E-Phanerogam-Angiosperm, edited by A. K. Sharma and A. SHARMA, Science Publishers, Enfield.

Byrne, M., M. I. Marquez-Garcia, T. Uren, D. S. Smith and G. F. MORAN (1996). Conservation and genetic diversity of microsatellite loci in the genus Eucalyptus. Australian Journal of Botany 44: 331-341.

CAUvin, B. (1988): Pistil treatments for improved fertility in hybridization of Eucalyptus gunni (Hook), pp. 321-325. In: Proceedings of the tenth international symposium on sexual reproduction in higher plants, edited by M. CResti, P. Gori and P. PACINI, University of Siena, Italy.

Charlesworth, D. and B. Charlesworth (1987): Inbreeding depression and its evolutionary consequences. Annual Review of Ecological System 18: 237-268. 
Chippendale, G. M. (1973): Eucalyptus of the Western Australia goldfields (and the adjacent wheatbelt), Department of Primary Industry, Forestry and Timber Bureau, Canberra, Australia.

Clark, N. B., S. M. READ and P. Vinden (1999): The effect of drought and salinity on wood and kraft pulps from young plantation Eucalyptus. Appita Journal 52: 93-97.

CONACHER, A. and J. CoNACHER (1998): Southern Australia, pp. 155-167. In: Land degradation in Mediterranean environments of the world: Nature and extent, causes and solutions, edited by A. J. CONACHER and M. SALA, John Wiley and Sons, Brisbane.

CrAig, G. F., D. T. Bell and C. A. AtKins (1990): Responses to salt and waterlogging stress of ten taxa of Acacia from naturally saline areas of Western Australia. Australian Journal of Botany 38: 619-630.

EDMANDS, S. (2007): Between a rock and a hard place: evaluating the relative risks of inbreeding and outbreeding for conservation and management. Molecular Ecology 16: 463-475.

EldRIDGe, K., J. Davidson, C. Harwood and G. VAN WyK (1994): Eucalyptus domestication and breeding, Clarendon Press, Oxford University.

Elliot, T. C. and M. BYRNE (2003): Genetic diversity within and between natural populations of Eucalyptus occidentalis (Myrtaceae). Silvae Genetica 52: 3-4.

FAO (1981): Eucalyptus for planting, Forestry Series no $11, \mathrm{FAO}$, Rome, Italy.

Goldstein, D. B., A. Ruiz Linarez, L. L. Cavalli-Sforza and M. M. FELDMAN (1995): Genetic absolute dating based on microsatellites and the origin of modern humans. Proceedings of National Academic Science, USA 92: 6723-6727.

GRIFFIN, A. R. and P. P. CotTeRIL (1988): Genetic variation in growth of outcrossed, selfed and open pollinated progenies of Eucalyptus regnans and some implications for breeding strategy. Silvae Genetica 37: 124-131.

HARBARD, J. L., A. R. GRIFFIn and J. EsPeJo (1999): Mass controlled pollination of Eucalyptus globulus: a practical reality. Canadian Journal of Forest Research 29: 1457-1463.

HARDNER, C. and W. TIBBITS (1998): Inbreeding depression for growth, wood and fecundity traits in Eucalyptus nitens. Forest Genetics 5: 11-20.

HARDNER, C. M. and B. M. PotTs (1995): Inbreeding depression and changes in variation after selfing in Eucalyptus globulus ssp globulus. Silvae Genetica 44: 46-54.

Hardner, C. M., B. M. Potts and P. L. Gore (1998): The relationship between cross success and spatial proximity of Eucalyptus globulus ssp globulus parents. Evolution 52: 614-618.

Harwood, C., P. Bulman, D. Bush, R. Mazanec and D. STACKPOLE (2001): Compendium of Hardwood Breeding Strategies, Joint Venture Agroforestry Program, Canberra, Australia.

HENDRATI, R. (2008): Screening for salt and/waterlogging tolerance, deployment systems and genetic diversity of Eucalyptus occidentalis Endl. for breeding, $\mathrm{PhD}$ Thesis, The University of Western Australia.

Herrero, M. and J. H. Hormanza (1996): Pistil strategies controlling pollen tube growth. Sexual Plant Reproduction 9: 343-347.

HU, Y., J. J. OERTLI and U. SChMidHALTER (1977): Interactive effect of salinity and macronutrient level on wheat. Journal of Plant Nutrition 20: 1155-1177.

Hunt, N. and B. GILKES (1992): Farm Monitoring Handbook: a practical down-to-earth manual for farmers and other land users, The University of Western Australia, Perth.

Jones, T. H., D. A. Steane, R. C. Jones, D. Pilbeam, R. E. VAillancourt and B. M. PotTs (2006): Effects of domestication on genetic diversity in Eucalyptus globulus. Forest Ecology Management 234: 78-84.

LIU, K. and S. V. MuSE (2005): Powermarker: Integrated analysis environment for genetic marker data. Bioinformatics 21: 2128-2129.

Loo-Dinkins, J. (1992): Field Test Design, pp. 96-139. In: Handbook of quantitative forest genetics, edited by L. Fins, S. T. FRIEDMAN and J. V. BROTSCHOL, Kluwer Academic Publishers, Dordrecht, The Netherlands.

Marcar, N. E., D. CRaWford, P. Leppert, T. Jovanovic, R. FLOYD and R. FARROW (1995): Trees for Saltland: a guide to selecting native species for Australia, CSIRO Division of Forestry, Canberra.

MarcaR, N. E. and D. F. CRAWFord (2004): Trees for Saline Landscapes, RIRDC Publication Number 03/108, Canberra, Australia.

Marcar, N. E., D. F. Crawford, A. K. M. A. Hossain and A. T. Nicholson (2003): Survival and growth of the tree species and provenances in response to salinity on a discharge site. Australian Journal of Experimental Agriculture 43: 1293-1302.

Marcucci Poltri, S. N., N. Zelener, J. Rodriguez Traverso, P. GeLID and H. E. Hopp (2003): Selection of a seed orchard of Eucalyptus dunnii based on genetic diversity criteria calculated using molecular markers. Tree Physiology 23: 625-632.

Lowe, A., S. HARRis and P. Ashton (2004): Ecological genetics: design, analysis and application. Blackwell Publishing, Victoria, Australia.

Moncur, M. W. (1995): Techniques for pollination Eucalyptus, ACIAR Technical Reports 34, ACIAR, Canberra, Australia.

Munns, R. and A. TERMAAT (1986): Whole-plant responses to salinity. Australian Journal of Plant Physiology 13: $143-160$.

Pepper, R. G. and G. F. Craig (1986): Resistance of selected Eucalyptus species to soil salinity in Western Australia. Journal of Applied Ecology 23: 977-987.

PotTs, B. M. and B. CAUvin (1988): Inbreeding and interspecific hybridization in Eucalyptus, pp. 1-17. In: Proceedings of the International Forestry Conference of the Australian Bicentenary, Australia, AFDI-AlburyWodonga.

PotTs, B. M and R. J. E. WiltshiRe (1997): Eucalyptus genetics and genecology, pp 56-91. In: Eucalyptus ecology: individuals to ecosystems, edited by J. WILLIAMS and J. WoINARski, Cambridge University Press, Cambridge.

SedGley, M. and A. R. GRIFFIN (1989): Sexual reproduction of tree crops. Academic Press, London.

SHANNON, M. C. (1997): Genetics of salt tolerance in higher plants, pp. 265-280. In: Strategies for improving salt tolerance in higher plants, edited by P. K. JAIWAL, R. P. Singh and A. Gulati, Science Publishers, New Hampshire, USA

Steane, D. A., R. E.Vaillancourt, J. Russell, W. Powell, D. Marshall and B. M. Potts (2001): Development and characterisation of microsatellite loci in Eucalyptus globulus (Myrtaceae). Silvae Genetica: 50, 89-91.

Trindade, H., L. C. Boavida, N. Borralho and J. A. FEIJO (2001): Successful fertilization and seed set from pollination on immature non-dehisced flowers of Eucalyptus globulus. Annals of Botany 87: 469-475. 
Van der Moezel, P. G., G. V. N. Pearce-Pinto and D. T. BELL (1991): Screening for salt and waterlogging tolerance in Eucalyptus and Melaleuca species. Forest Ecology and Management 40, 27-37.

WILLI, Y. and J. BUSKIRK (2005): Genomic compatibility occurs over a wide range of parental genetic similarity in an outcrossing plant. Proceedings of the Royal Society of London. Series B, Biological Sciences. Royal Society, London, 272: 1333-1338.

Williams, D. R., B. M. Potts and P. G. Black (1999): Testing single visit pollination procedures for Eucalyptus globulus and E. nitens. Australian Forestry 62: 346-352.
YANCHUK, A. D. (2001): A quantitative framework for breeding and conservation of forest tree genetic resources in British Columbia. Canadian Journal of Forest Research 31: 566-576.

Zobel, B. J. and J. TAlberT (1984): Applied Forest Tree Improvement, Wiley, New York.

ZoHAR, Y. (1991): Performance of seedlings from selected sources of Eucalyptus occidentalis in a semi-arid Mediterranean-type environment. South African Forestry Journal 159: 37-41.

\title{
Genetic structure and diversity of Polylepis australis (Rosaceae) tree populations from central Argentina: Implications for forest conservation
}

\author{
By N. B. Julio ${ }^{1)}$, J. C. Rondan Dueñas ${ }^{1)}$, D. Renison ${ }^{2), *}$ and I. Hensen ${ }^{3)}$
}

(Received $4^{\text {th }}$ September 2009)

\begin{abstract}
Worldwide, large areas of forest are being transformed to other land cover types and the resulting fragmented populations may suffer from restricted gene flow leading to genetic pauperization and increased inbreeding. To assess the genetic constitution of fragmented Polylepis australis mountain forests of central Argentina, analyses of the structure and diversity of ISSR markers were carried out for 90 trees distributed throughout five river basins with differing degrees of fragmentation. Overall, average polymorphism $(P)$ ranged between 87.2 and $94.9 \%$ (95\% criterion) while marker diversity index $(M)$ varied between 0.35 and 0.39 ; values which are comparable with other wind-pollinated tree species. Analysis of molecular variance (AMOVA) revealed that most genetic variation occurred within river basins $(97.8 \%)$, with only a little occurring between river basins $(2.2 \%$; $\Phi_{S T}=0.02$ ). In addition, Mantel's test indicated that $P$. australis does not follow the usual pattern of isolation by distance; instead the UPGMA method showed that trees from the two most degraded river basins formed a group while trees from the three better pre-

1) Cátedra de Genética de Poblaciones y Evolución, Universidad Nacional de Córdoba. Velez Sarsfield 299, 5000 Córdoba, Argentina.

2) Centro de Ecología y Recursos Naturales Renovables Dr. Ricardo Luti (CERNAR), Facultad de Ciencias Exactas, Físicas y Naturales, UNC - CONICET, Av. Vélez Sarsfield 1611, X5016GCA Córdoba, Argentina.

$\left.{ }^{3}\right)$ Institute of Biology, Geobotany and Botanical Garden. MartinLuther-University Halle-Wittenberg, Am Kirchtor 1, D-06108 Halle, Germany.

*) Corresponding author: Fon 54-351-4334141.

E-mail addresses: darenison@yahoo.com.ar danielrenison@ecosistemasarg.org.ar
\end{abstract}

served basins formed another. As such, either effective pollen flow has maintained high levels of genetic diversity, or present day genetic variability is a remnant of a recently fragmented ancestral panmictic population. We conclude that, at present, genetic degradation in $P$. australis populations of central Argentina is not as important as ecological degradation - such as soil loss, intensive browsing by livestock or increased frequencies of wildfires, and that genetic variability is still fully available for forest restoration.

Key words: fragmentation, genetic diversity, Polylepis australis, Argentina, conservation, ISSR.

\section{Introduction}

Worldwide, large areas of forest are being been felled for timber, burnt or clear-cut to produce grasslands for livestock, agricultural lands or urban areas, all of which are changing the face of forest landscapes across the globe (CINGOLANI et al., 2008; ZAK et al., 2004; SPIES, 1998; EllenBerG, 1979). The resulting fragmented forest landscapes may have tree populations with diminished effective population sizes, decreased gene flow and increased inbreeding and eventually may produce high differentiation among remnant populations (JUMP and PEÑUElAS, 2006). However, this pattern has exceptions, as some species compensate fragmentation with increased gene flow through greater pollen or seed dispersal distances (FRANKHAM et al., 2002). Determining the genetic structure of fragmented tree populations is necessary for detecting any possible genetic loss due to inbreeding within fragments and for planning any adequate restoration action with regards to genetic differentiation and variability. Forest restoration is important 